ARCHIVO ESPAÑOL DE ARTE, LXXXII, 328

OCTUBRE-DICIEMBRE 2009, pp. 355-366

ISSN: 0004-0428

\title{
GÁMIZ, ANCHIETA Y JUNI. EL PLEITO POR EL RETABLO DE BRIVIESCA
}

POR

\author{
Luis VASALLO TORANZO
}

El hallazgo del pleito entre el escultor Pedro López de Gámiz y el condestable de Castilla por la tasación del retablo mayor de Santa Clara de Briviesca permite desenmarañar su largo proceso de elaboración y conocer a la mayoría de los oficiales que intervinieron en su ejecución. Las críticas de Juni a la arquitectura y composición de la obra hicieron aflorar viejos resentimientos contra el francés. Por ultimo, se aclara definitivamente la participación de Anchieta en el taller de Briviesca, que fue decisiva, y se proporcionan abundantes testimonios sobre su fama y valía.

Palabras clave: Escultura romanista; Retablo mayor; Briviesca; Pedro López de Gámiz; Juan de Anchieta; Juan de Juni; Pedro de Arbulo; Juan Fernández de Vallejo.

The discovery of the lawsuit between the sculptor P. López de Gámiz and the Constable of Castile for the valuation of the main altarpiece of Santa Clara de Briviesca, has allowed for the clarification of the long working process involved in its creation as well as the identification of most of the craftsmen involved in the project. Following Juni's criticism of the architecture and composition of the structure, old resentments toward this French sculptor resurfaced. Lastly, Anchieta's decisive participation in the Briviesca workshop is definitively clarified, along with abundant evidence concerning his fame and ability.

Key words: Mannerist sculpture; High Altar; Briviesca; Pedro López de Gámiz; Juan de Anchieta; Juan de Juni; Pedro de Arbulo; Juan Fernández de Vallejo.

Inédito ha permanecido en el Archivo de la Real Chancillería de Valladolid el pleito que enfrentó a Pedro López de Gámiz con el condestable de Castilla a causa de la tasación del retablo de Santa Clara de Briviesca ${ }^{1}$. Hasta este momento la escasa documentación que se había podido recoger sobre la obra era parcial y equívoca, proporcionada por una ejecutoria ganada por las

${ }^{1}$ El pleito se halla en el Archivo de la Real Chancillería de Valladolid, Pleitos Civiles, Zarandona y Walls (F), C. 3114-1. Se trata de un largo documento de unos 1.000 folios. Por motivos editoriales, he tenido que prescindir de las citas concretas al mismo, por lo que toda aquella información que no cuente con su correspondiente aparato crítico se entenderá procede de él. La ejecutoria expedida en favor de Gámiz está en AChVa, Reales Ejecutorias, C. 1284-10. 
monjas de Briviesca al condestable ${ }^{2}$ y por unas alegaciones del procurador del patrono en el pleito que nos ocupa ${ }^{3}$. Estas noticias habían sacado a la luz los nombres de los contratistas, Diego Guillén y Pedro López de Gámiz, así como los de los tasadores y testigos presentados por el condestable, entre ellos Juni y Portigiani; pero permanecía sin aclarar el inicio exacto de la obra, que se supuso sin fundamento alguno anterior al retablo de la catedral de Astorga, y se mantenía en el anonimato el tasador aportado por Gámiz y los oficiales que trabajaron con él.

A todas esas cuestiones da cumplida respuesta el documento, que recoge además las duras críticas vertidas por Juni a la composición del retablo y es muy explícito en cuanto a la participación crucial de Anchieta.

El pleito, iniciado en 1571, terminó tres años después con la condena al condestable a pagar 10.000 ducados, de los que habría que descontar los casi 5.000 abonados a Guillén y Gámiz a lo largo de los doce años que duró la obra ${ }^{4}$.

\section{El proceso constructivo}

El 6 de mayo de 1559, todavía en vida del condestable don Pedro Fernández de Velasco, que moría pocos meses más tarde en Valladolid, el imaginario Diego Guillén contrataba el retablo mayor del convento de Santa Clara de Briviesca. Según la traza presentada por el artista, el retablo era de planta recta y estaba distribuido en tres calles, la central el doble de ancha que las laterales, y tres cuerpos más un ático.

La advocación del retablo era la de la Inmaculada Concepción. La imaginería prevista coincidía básicamente con lo que después se talló: un apostolado en las entrecalles, grandes relieves de la vida de la Virgen en las calles laterales, y el Árbol de Jessé y las imágenes de la Virgen con el Niño y de la Asunción en la central. De esta parte nuclear del retablo sólo se varió posteriormente el Árbol de Jessé, que originalmente incluía una caja con el Abrazo ante la Puerta Dorada entre las ramas, y los relieves de la predela.

La pronta desaparición del primer comitente y las dudas generadas por un proyecto ajeno a las novedades introducidas por Becerra en Astorga y por Rodrigo y Martín de la Haya en la propia Burgos -desde 1558 el primero y a partir de 1561-2 los segundos- sin duda influyeron en el replanteamiento del proyecto. La más evidente deficiencia radicaba en su planta recta, que impedía cubrir en su totalidad los muros de la capilla mayor poligonal. Ello provocó un cambio de planes en vida de Guillén, que acarreó la adopción de la forma ochavada y la multiplicación de los elementos esculpidos.

Al escultor sólo le dio tiempo a terminar la mazonería e imaginería de la predela y primer cuerpo (denominados en la documentación dos primeros órdenes o bancos). Para aquélla talló el tabernáculo, los tableros de la Entrada en Jerusalén y de Cristo con la cruz a cuestas, y algunas imágenes de los netos. Para éste, la figura de Jessé y el relieve del Abrazo ante la puerta dorada.

\footnotetext{
${ }^{2}$ VaL, G. del, «España pintoresca. Briviesca y sus cercanías», Seminario Pintoresco Español, 1842, pp. 310-2 y Sanz García, J. «El retablo de Santa Clara de Briviesca (Estudio documental)», Boletín de la Comisión Provincial de Monumentos de Burgos, 48-54, T. IV, 1934-1937.

3 Vélez Chaurri, J. J., Becerra, Anchieta y la escultura romanista, Madrid, 1992, p. 24, y BARrón, A. y RUIZ DE La Cuesta, M. ${ }^{\text {P }}$., «Notas sobre el retablo de Santa Clara de Briviesca», AEA, 279, 1997, pp. 257-267.

${ }^{4}$ El escaso celo de los mayordomos del condestable no permitió concretar la cifra exacta pagada a Guillén y Gámiz hasta la finalización de la obra. La última carta de pago firmada por Gámiz el 29 de noviembre de 1571, sumaba en torno a 4.800 ducados (AChVa, Pl. Civiles. Quevedo (F), C. 1170-6).
} 
Como es sabido, muerto Guillén, acudió Pedro López de Gámiz a Villalpando el 2 de marzo de 1566 para contratar el retablo. Básicamente la escritura contenía el compromiso de respetar el proyecto del maestro anterior y mantener o superar su calidad. Aunque resulte sorprendente, lo cierto es que Gámiz no había visto la traza original cuando firmó el contrato, y desconocía que ésta no coincidía con lo ejecutado hasta entonces.

Aquí radica el origen del pleito, pues Gámiz decidió prescindir de la traza original para adaptarse a la forma ochavada de la predela y primer cuerpo entregados por Guillén. Estos dos "órdenes" constituían la planta, tantas veces reseñada durante el pleito y que tantas conjeturas ha provocado. También resolvió Gámiz prolongar en altura la máquina hasta llenar completamente la capilla mayor, y multiplicar la obra escultórica y ornamental, ejecutada por los mejores oficiales que pudo encontrar.

No se indica exactamente en el pleito cuándo reinició Gámiz el retablo, aunque sí que fue a lo largo de 1566; posiblemente a mediados de dicho año, pues algunos testigos declaran que los trabajos de Gámiz se prolongaron durante seis anualidades ${ }^{5}$. En 1571 se puso fin a la obra. Durante ese tiempo labraron continuamente entre ocho y diez oficiales; a veces más. Algunos de ellos se asociaron al taller y permanecieron todo el tiempo con el maestro; la mayoría, sin embargo, venía cuando los requería Gámiz, atraídos por las suculentas soldadas, que en el caso de Anchieta, el mejor pagado, alcanzaba los 9 reales diarios.

Se conocen muchos de los oficiales. Entre los ensambladores se citan a Enrique de Drus, que estuvo sólo dos meses en Briviesca; Pedro de Angulo, que permaneció largo tiempo, porque comenzó como aprendiz de Gámiz; Mateo de Murga; Domingo de Zumarán, que trabajó dos años y tres meses; Juan de Ybardia, presente en Briviesca desde el principio; Juan de Carranza el Mozo, sobrino de Gámiz, y Juan de Zaldegui. En condición de imaginarios y escultores participaron Pedro del Cerro, aprendiz que había sido de Gámiz y uno de sus oficiales de confianza; Hernando de Lubiano, que trabajó cuatro años en el retablo en diversas ocasiones; Agustín Ruiz, que estuvo todo el tiempo en Briviesca; Diego Cerezo, estante en Madrid en 1572, que participó sólo al principio; Francisco Vázquez, que ayudó a descargar los bancos de Guillén y que labró durante más de tres años; y sobre todo Juan de Anchieta. Éste, que declaró contar 34 años de edad en el verano de 1572, lo que obliga a retrasar su nacimiento hasta 1538, aclara que labró en la dicha obra mucho tiempo y que acudió con un aprendiz llamado Antonio Martínez de Rueda, presumible hijo de Antonio Martínez, su maestro.

El elevado número de artífices resultó muy oneroso para Gámiz, que importunaba al comitente con repetidas solicitudes de dinero. Esto provocó la reacción del condestable don Íñigo Fernández de Velasco que sustituyó al veedor y promovió un nuevo contrato con Gámiz el 4 de octubre de 1569, en el que se insistía en el respeto a la traza original.

Cuando se terminaron de montar el segundo y tercer cuerpos del retablo en septiembre de 1569, ya estaban diseñados el remate y el Calvario. Gámiz había transformado el proyecto de Guillén -un frontispicio con un relieve de un Dios Padre, además de un sencillo Calvario en lo alto- en un cuarto cuerpo más un Calvario que incluía a la Magdalena y los dos ladrones, además de dos profetas; todo para ocupar la altura de la capilla mayor.

Aunque, según el nuevo contrato firmado por Gámiz, el retablo se debía acabar el último día de marzo de 1571, lo cierto es que eso no ocurrió hasta el otoño. Fue entonces cuando se procedió a llamar a los tasadores. El mirandés solicitó a Pedro de Arbulo y el condestable a Juan de Juni. Las diferencias surgidas entre ellos motivaron que el alcalde de Briviesca eligiese a Juan

\footnotetext{
${ }^{5}$ Esto contrasta con lo expresado por DíEz JÁviz, C., Pedro López de Gámiz escultor mirandés del siglo XVI, Miranda de Ebro, 1985, p. 40, que suponía la llegada de Gámiz a Briviesca en 1567. Sobre López de Gámiz ver también Andrés Ordax, S., El foco de escultura romanista de Miranda de Ebro. Pedro López de Gámiz y Diego de Marquina, Valladolid, 1984.
} 
Bautista Portigiani como árbitro, nombre propuesto posiblemente por su amigo Juan de Juni. La pretensión del condestable de que se valorase la obra por la traza de Guillén y el desacuerdo de Gámiz con la tasación ocasionaron el litigio.

\section{Vicios y virtudes de la obra. El enfrentamiento Gámiz-Juni}

El relato de la peripecia constructiva del retablo entre 1559 y 1571 permite aclarar algunas dudas mantenidas hasta ahora. Se puede desechar definitivamente la supuesta primacía del proyecto de Briviesca sobre el de Astorga, puesto que es un año posterior. Igualmente, es preciso desestimar la intervención de Becerra durante su estancia burgalesa de 1557. Por último, una vez conocido el proyecto de Guillén y su ampliación cuando ya se había comenzado el retablo mayor de la Catedral de Burgos, es obligado vincular su traza a las formas tradicionales del propio Guillén, renovadas por influencia de la gran máquina catedralicia.

Diego Guillén regentó uno de los talleres más activos de Burgos durante el tercio central del siglo XVI. Relacionado con Bigarny, aparece documentalmente unido a su viuda y a las obras de Gregorio Pardo en la década de $1540^{6}$. Precisamente en ese año murió el pintor Pedro de Torres el Viejo, padrastro de Guillén y activo contratista de retablos. Desde entonces empiezan a menudear las noticias sobre Guillén, quien ha sido documentado en obras de piedra y madera. Los retablos que se le han podido adjudicar, como el de Salas de los Infantes, responden a un esquema tradicional, con calles separadas por columnas abalaustradas y abundante decoración tallada ${ }^{7}$.

El proyecto original de Briviesca coincidía con las formas habituales de los entalladores de los focos burgalés y calceatense de mediados del siglo XVI: retablos de casillero con acotaciones laterales en forma de entrecalles salientes o de grandes columnas a modo de pulseras. Las sucesivas ampliaciones del retablo respetaron la organización ortogonal planteada originalmente por Guillén, pero multiplicaron las divisiones y cajas donde alojar imágenes y relieves. Todo ello, unido a la profusa decoración aplicada por Gámiz, que se extiende por toda la superficie disponible, es la causa de la sensación de abigarramiento y confusión que transmite la obra. Poco hizo Gámiz por afirmar la arquitectura, pues mantuvo algunos elementos tan arcaicos como las anticlásicas columnas achaflanadas y los "viajes" de los entablamentos, inservibles una vez ampliado lateralmente el retablo.

Los defectos señalados fueron identificados por Juni, quien participa con su tasación y declaración en la controversia sobre el decoro y la claridad expositiva contrarreformistas.

A mediados de noviembre de 1571 acudieron a Briviesca Pedro de Arbulo y Juan de Juni. Durante quince días revisaron la obra sin lograr ponerse de acuerdo en la tasación. Arbulo se mostró absolutamente favorable al mirandés al tasarla en 13.069 ducados. Juni la rebajó hasta 10.700 , justificándolo con críticas severas. Portigiani acudió en febrero del año siguiente y la valoró en 11.540. Las censuras y la cicatería de los tasadores provocaron la reacción desairada del contratista.

Comienza el francés con una alabanza del retablo, al cual califica de muy prinçipal y muy bueno. Considera, además, que las sucesivas ampliaciones hasta conseguir henchir la capilla lo habían magnificado: que está bien acomodado a la capilla, en la qual representa mucha magestad. Tras esto, y a preguntas del juez de Briviesca -criado del condestable al fin y al cabo- sobre si en el retablo hay obra de talla y escoltura superfular, y en partes donde la tal talla y escultura

\footnotetext{
${ }^{6}$ Río de LA Hoz, I. del, El escultor Felipe Bigarny (h. 1470-1542), Salamanca, 2001, pp. 324 y 340-2.

7 Barrón, A. y Ruiz de la Cuesta, M. ${ }^{a}$ P., «Diego Guillén, imaginero burgalés (1540-1565)», Artigrama, 10, 1993, pp. 248 y ss.
} 
sea ynútil e sin probecho ni decoro e adorno de la obra, responde que la abundancia de talla $e$ menudençias de escultura questán en partes altas donde no alcança la bista y en otros lugares en donde está ynpertinente sin hazer adorno ni probecho... pone confusión en la obra porque es demasiado, y con menos sería la obra más complida e más graçiosa.

Significativamente, el francés insiste sobre lo mismo cuando el juez le pide que declare si el retablo se acomoda a la traza de Guillén. Después de señalar las diferencias observa: $E$ a lo que susodicho tengo serca de la multitud de talla que está en la obra, torno a desir que ... con menos ... se pudiera aber rrebestido e adornado muy artistemente todo el rretablo, e fuera muy más graçioso e de mejor apariençia que siendo ofoscado de mucha talla e menudençias descoltura como lo está, ... porque entre buenos artífiçes nunca se entendió ni se entiende que consista la bondad y estimaçión de semejantes obras e(n) muchas menudençias de talla aplicada e cargada sin horden como en este rretablo lo está, sino en buena archetetura, hordenada por buen arte, e con poca talla bien rrepartida en sus debidos lugares, e probeidas de buena escoltura como lo tiene el dicho rretablo, e por tal lo tengo e se puede tener e estimar en lo demás.

La declaración de Juni supuso un duro golpe para Gámiz, que veía rebajadas sus pretensiones económicas y tenía que soportar la crítica del más prestigioso de los escultores.

Meses más tarde, cuando Juni acude a Briviesca para declarar a favor del condestable, se muestra más prudente y sólo señala que le paresçe que se pudiera haçer otro rretablo de menos costa e más graçiosso, e que bastara para el dicho monesterio e capilla... Junto a él acudieron otros artistas, también llamados por el condestable. Casi tan lacónicamente como Juni se expresó el arquitecto Juan de Salamanca, hijo de Francisco de Salamanca, quien se limitó a señalar que el retablo va muy fuera de la horden de la alquitatura. Más preciso fue Alonso Falcote: ...que le paresçe que se pudiera haçer otro rretablo de mejor traça e más desenbuelto, e paresçiera mejor el dicho rretablo... Porque la traza desocupaba el serviçio de la dicha capilla, porque (ahora) salen dos cubos, de manera que envarazan la capilla e vista de los questán a los lados, estando como está la pared de la dicha capilla derecha, y el dicho rretablo pudiera yr derecho conforme a la pared, e no hiçiera los cuvos ni envaraçara. No le faltaba razón a Falcote, puesto que en realidad la planta del retablo no es de tres ochavos, como la capilla mayor, sino de cinco; lo que provoca, dada la estrechez del presbiterio, una posición muy oblicua de las calles laterales, que dificulta la contemplación de los relieves y oculta completamente las figuras de santos que hay junto a ellos. Le llaman también la atención los remates curvos de las entrecalles laterales, en realidad añadidos por Gámiz después de realizar el retablo de Santa Casilda y empleados por maestros del foco burgalés de la generación anterior (por ejemplo, por Domingo de Amberes en Mahamud), tildando por este motivo a la totalidad de dichas entrecalles como cubos, cuando una solución similar, sin las formas curvas, se había adoptado también en el retablo mayor de la catedral de Burgos.

Tradicionalmente se ha criticado la articulación del retablo de Briviesca, fundamentalmente de los laterales donde se acumularon las adiciones ${ }^{8}$. Pero más que en esto, o en la reiteración de unos órdenes de escaso porte, que producen sensación de aplastamiento contra el muro, Juni insiste en el desequilibrio patente entre arquitectura y talla. En Briviesca volvía a imponerse claramente la figuración. Un paso atrás que chocaba frontalmente con el proceso iniciado por el francés en el retablo de La Antigua, al que se había sumado desde 1558 Gaspar Becerra en los de Berceruelo (Valladolid), Astorga y Santa María de Medina de Rioseco. Numerosos discípulos de ambos maestros continuaron dicha senda en retablos como el de La Magdalena de Valladolid, Simancas, Villabáñez o Tudela de Duero, caracterizados por la claridad de la composición arquitectónica y el enorme tamaño de sus relieves y figuras. En 1571-2 la composición del retablo de

\footnotetext{
${ }^{8}$ MARÍAs, F., El largo siglo XVI, Madrid, 1989, p. 607.
} 
Briviesca tenía que parecer anticuada para los maestros vallisoletanos. La visión de esta máquina, repleta de talla ornamental y narrativa, dividida en multitud de calles donde se alojan innumerables figuras y relieves, tuvo que traerle a Juni recuerdos del lejano pleito de La Antigua ${ }^{9}$.

Juni busca argumentos para oponerse a Gámiz y los encuentra en los lugares comunes del tratamiento contrarrefomista de las imágenes ${ }^{10}$. El escultor vallisoletano y los representantes del condestable asesorados por él emplean la terminología al uso para referirse al decoro y la claridad argumental: gracia, apariencia, arte, orden, provecho... frente a superfluo, ofuscado, menudencia, prolijo, impertinente, inútil...; pero no aportan razonamiento teórico alguno para oponerse a la articulación del retablo ${ }^{11}$.

Una segunda crítica de Juni se centra en el valor de la obra, totalmente desproporcionado para el convento de una villa de pequeño tamaño, como dice alguno de los interrogados sin tener en cuenta la calidad del patrono. En su declaración como testigo el francés censura la desmesura del retablo, que sobrepasaba todo lo razonable, tachándolo hiperbólicamente como el más costoso de la cristiandad: ... que de tamaño que tiene, en este rreyno ni aun en la cristiandad piensa este testigo que no ay rretablo tan costoso, aunque este testigo a visto muchos rretablos rricos e de mucho valor; para inmediatamente apostillar: aunque en arte no es mejor ni tan bueno como otros muchos... Juni llega a calcular el coste total, una vez policromado, en 25.500 ducados.

De la misma opinión es su hijo Isaac, quien además informa de un viaje fuera de España: que ha conocido en estos reinos e fuera dellos muchos rretablos e costosos, pero declara que jamás a visto rretablo tan costoso como él, de su manera e tamaño.

Todos los testigos, sin excepción, apuntan que el retablo era uno de los sobresalientes del reino, incluso el más gravoso de los realizados en Castilla hasta ese momento. Como testimoniará Arbulo, Juni se sintió agraviado ante una obra tan desorbitada, realizada por un mediano escultor que había trabajado para él en alguna ocasión. Los 14.000 ducados que pedía Gámiz multiplicaban varias veces los precios cobrados habitualmente por el francés (2.400 ducados por el de La Antigua con la policromía y más de 1.000 por la mitad del de El Burgo de Osma) o por Becerra (3.000 ducados por el de Astorga). Diferencia de la que Juni tomó buena nota para escriturar en 8.000 ducados el de Santa María de Medina de Rioseco en 1573.

Por supuesto, estas críticas tienen una finalidad única y exclusivamente económica, con vistas a conseguir una rebaja sustancial en el precio de la obra. Se pretendía descargar sobre Gámiz la responsabilidad de obra tan desmesurada, aunque para ello hubiese que apelar a razonamientos comprometidos. Haciendo gala de una peligrosa sintonía con rancios argumentos erasmistas ${ }^{12}$, Portigiani no encuentra reparos en tachar la obra de locura, sobre todo ante las necesidades de las propias monjas y de los pobres de Briviesca: ...lo tiene este testigo por locura, porque la yglesia a do está puesto (el retablo) toda ella no costó tanto dinero, y las monjas que sirben a la dicha yglesia ... padesçen de hambre muchas vezes por lo poco que tienen para sus mantinimientos. E más save este testigo quel ospital que se a de hazer, con los dineros que se gastan para las

\footnotetext{
${ }^{9}$ Martí Y Monsó, J. Estudios Histórico-Artísticos relativos principalmente a Valladolid, Valladolid, 1901, pp. 334 y 338 .

10 Martínez-Burgos García, P., Ídolos e imágenes. La controversia del arte religioso en el siglo XVI español, Valladolid, 1990, pp. 233 y ss.

11 Contrasta la endeblez argumental de estos ensambladores y escultores con la autoridad de un arquitecto como Ribero Rada en un caso similar, también burgalés, diez años más tarde. BARRÓN GARCíA, A., «Fantasía y clasicismo. Debate sobre un retablo para el monasterio de la Merced de Burgos», Actas del X Congreso del CEHA. Los Clasicismos y el Arte Español, Madrid, 1994, pp. 211-7.

12 Similares a los que algunos administradores del Hospital de Santa Cruz de Toledo adujeron cuando se contrató el retablo con Bigarny y Coomontes (Río DE LA Hoz, I. del, El escultor Felipe Bigarny (h. 1470-1542), Junta de Castilla y León, Salamanca, 2000, p. 289), sólo que treinta años después.
} 
obras de la dicha yglesia, no está aún empezado el dicho ospital; e tiene este testigo entendido que haze grande falta para los povres del dicho lugar de Bribiesca e su tierra... Juni se abstendrá de emitir juicios sospechosos, puesto que ya había tenido un desagradable encuentro con la Inquisición en $1567^{13}$.

Hasta aquí las críticas. A ellas respondió Gámiz convocando a los mejores escultores de los focos burgalés y calceatense, a quienes encargó valorar conjuntamente el retablo. Tras ello, los sometió a un interrogatorio sobre la bondad de la escultura y necesidad de la talla decorativa para realizar una obra acorde con la categoría del promotor. Por ultimo, intentó desprestigiar a Juni, a quien tachó de enemigo de España y, en particular, de los escultores españoles.

Vayamos por partes. Ninguna de las tres tasaciones realizadas oficialmente satisfacían al mirandés. Para alcanzar una pretendida valoración objetiva, Gámiz convocó a los mejores escultores del entorno, a excepción de Arbulo. En julio de 1572 se presentaron en Briviesca Juan Fernández de Vallejo, Rodrigo de la Haya, Martín de la Haya, Juan de Anchieta, Simón de Cambray, Juan de Esparza, Nicolás de Venero, Bartolomé de Angulo y Diego de Marquina. Todos juntos analizaron la obra detenidamente durante cinco o seis días: ...e viendo que el dicho rretablo hera tan rrico e que abía en él mucho que ver, e para que con buena conçençia pudiesen dezir lo que puede baler, acordaron de todos nuebe, ansí como estaban juntos, de ber el dicho rretablo pieça por pieça, e por pluma e papel ir començando a le ttasar. Finalmente, acordaron valorar el retablo en 13.887 ducados, cifra que se acercaba mucho a los 14.000 pretendidos por Gámiz.

El estudio pormenorizado realizado por estos maestros resultó definitivo para la afirmación del arte de Anchieta en el noreste castellano. Su escultura fue analizada y estudiada por muchos de los escultores que pasaron por Briviesca. No se explica de otra manera la inmediata influencia ejercida por el guipuzcoano sobre Juan Fernández de Vallejo o Diego de Marquina, por ejemplo; pero también sobre Martín de la Haya, a veces relacionado con Agustín Ruiz ${ }^{14}$, uno de los oficiales destacados del taller de Briviesca. De hecho, parece indudable que en la fama ganada por Anchieta en Briviesca se encuentra una de las causas del abandono de Valladolid y de su asentamiento en el norte.

A estos mismos nueve artífices interroga Gámiz sobre la calidad de la obra y la necesidad de la labor de talla. Todos sin excepción alaban el retablo y justifican la proliferación decorativa en las obligaciones contractuales de Gámiz. Con todo, parece fuera de toda duda que su inclinación empresarial y su conocimiento del sistema de contratación a tasación le indujeron a enriquecer la obra. Gámiz conocía el doble componente de las tasaciones: el cuantitativo o artesanal y el

\footnotetext{
13 No se conoce el motivo del encarcelamiento de Juni (Bustamante García, A., «El Santo Oficio de Valladolid y los artistas», BSAA, LXI, 1995, p. 458), y nada se puede aventurar a tenor de los escasos datos que se tienen. Poco ayuda a este respecto el reducido número de libros conocido de Juni (MARTí Y Monsó, J., ob. cit., p. 483 y FERnÁNDEZ DEL Hoyo, M. A., «Datos para la biografía de Juan de Juni», BSAA, LVII, 1991, pp. 333-340). Tampoco, el probable acercamiento a presupuestos derivados de la devotio moderna, dada su vinculación con la orden franciscana, y concretamente con el antierasmista obispo de Mondoñedo (PARRAdo DEL Olmo, J. M. ${ }^{\mathrm{a}}$, Las tendencias de la escultura vallisoletana a mediados del siglo XVI (1539-1562), Valladolid, 2004, pp. 40-2 y 51 y ss.) o con el almirante Fadrique Enríquez, uno de los alumbrados (Bataillon, M., Erasmo y España, México, 1950, pp. 183-5). Quizás fueran sus contactos con la colonia extranjera de Valladolid los que alertaron a la Suprema. Como se dice en el pleito de Briviesca, era evidente su inclinación hacia los extranjeros, en particular hacia sus compatriotas y algunos italianos. Su hijo Isaac trabajó con Jamete y Rabuyate; una larga amistad unió al genio con Portigiani y Rabuyate. Sin duda se relacionó con Pompeyo Leoni, asimismo encarcelado por la Inquisición durante su primera estancia vallisoletana. Sobre la inclinación de Juni por los extranjeros, vinculada también a su detención por el Santo Oficio, ver últimamente Urrea, J., «Revisión y novedades junianas en el V Centenario de su nacimiento», Boletín del Museo Nacional de Escultura, 10, 2006, p. 4.

14 Barrón García, A., «Los escultores Rodrigo y Martín de la Haya», Boletín del Museo e Instituto «Camón Aznar», LXVI, 1996, p. 33.
} 
cualitativo o artístico ${ }^{15}$. Para dar cumplimiento al primero acrecentó "las manos" o trabajo mecánico multiplicando la talla ornamental. Para alcanzar el segundo contrató a los artífices más cualificados, a la espera de la mejor retribución a su inversión. Su deseo era realizar una obra singular que mereciese la recompensa de patrono tan excelente como el condestable. De hecho, así se manifestó el italiano Portigiani en su tasación, quien debido a su origen se inclina a confundir las obligaciones del patronazgo con la liberalidad del mecenazgo: ... de la manera e arte quel dicho rretablo está, ... meresçía el ser pagado a la boluntad de liberal señor e no al albitrio de tasadores...

Una vez probada la bondad del retablo, Gámiz intenta desacreditar a Juni, llegando hasta la calumnia: Yten, si saben, etcétera, quel dicho Juan de Juni, vezino de Valladolid, hes françés de naçión, e a sido y es contrario y enemigo de la naçión castellana, mayormente de los hescultores, e por consiguiente a sido y es enemigo del dicho Pedro López de Gámiz...

Dado el magisterio ejercido por Juni durante el tercer cuarto del siglo XVI, los silencios, al menos entre los escultores más afamados, son más significativos que las respuestas agresivas. De entre los prudentes que callaron se cuentan algunos que lo conocían bien como Anchieta, Rodrigo y Martín de la Haya, Nicolás de Venero, Bartolomé de Angulo y Simón de Cambray. De entre los que testificaron contra Juni, algunos lo hicieron sólo de oídas como Juan de Esparza, Diego de Marquina, Enrique de Drus, Pedro del Cerro, Pedro de Angulo, Agustín Ruiz o Hernando de Lubiano; otros, sin embargo, con conocimiento de causa, por haberlo tratado o trabajado en su casa. Todos coinciden en el nacionalismo rancio e interesado de Gámiz.

Pedro de Angulo dice que ha oído ...que el susodicho hera enemigo rrealmente de la naçión hespañola, hespeçialmente de los de la arte de su ofiçio; tanto que pretende, e lo dize, que los hespañoles son unas bestias e gentes mal entendidas... De la misma opinión es Juan de Esparza, quien además añade un dato expresivo del nivel de exigencia que Juni imponía a su oficiales: ...que en viendo alguna figura que aya echo algún ofiçial hespañol en su casa e no le contentando la aze pedaços. Su predilección por los extranjeros la ratifica Juan de Ybardia, ensamblador que trabajó en su casa durante cuatro meses en 1568 ó 1569: ...conoçió dél que a ofiçiales castellanos, si no hera no poder más, no los quisiera, antes hera amigo de hestranxeros. Este mismo llega a acusar a Juni de ocultarle algunos conocimientos de su oficio mientras trabajó con él-...algunas cosas él pudiera a heste testigo enseñar mejor, que él aprovechava-; aunque como dice Isaac de Juni, Ybardia hera ensamblador e no muy bueno. Muy llamativa es la declaración de Antonio Martínez de Rueda, imaginario, vecino de Medina de Rioseco, quien reconoce haber estado en casa de Juni y declara que por cossa pública en Valladolid y en otras partes a hoydo dezir quexándose perssonas artífizes en la dicharte del dicho Juan de Juany, deziendo que dezía de todo a los artifizes hespañoles mal, e que mostraba hestar mal con ellos. Lo mesmo cree estaría con Pedro López de Gámiz, e que dezía mal de sus obras aunque paresçía al contrario.

De entre los escultores destacados que testifican para Gámiz, sólo Juan Fernández de Vallejo y Pedro de Arbulo consienten en contestar a la pregunta contra Juni. El primero, que no en vano había sido su oficial durante año y medio, trata de encontrar una explicación a la enemistad entre el francés y Gámiz: $Y$ se a dicho entre algunas personas que no tiene memoria, que el dicho Juan de Juni si estaba mal con el dicho Pedro López de Gámiz era porque le avían dicho que el dicho Pedro López avía dicho mal dél; e al mismo Pedro López le a hoydo dezir debaxo de juramento que tal no abía dicho. Aunque tiene que reconocer que Juni ...no hes afiçionado a españoles ni

15 Como dice Portigiani la valoración depende de la calidad del artífice, porque por una misma traça haçiéndose la obra por mano de buen ofiçial biene a baler más que si estubiese hecha por mano de mal ofiçial. ...Que la obra ... seyendo muy bien hecha podía baler mill ducados más, e seyhendo mal hecha podría baler mucho menos. Sobre las problemáticas tasaciones el caso más conocido es el del Greco. Gállego, J., El pintor de artesano a artista, Granada, 1976, pp. 101 y ss. 
está muy bien con los hescultores hespañoles. E lo que en él conoçe y en su entendimiento, a los hespañoles no los tiene por bien entendidos. Así se lo a hoydo dezir.

Rencor es lo que transmite la deposición de Pedro de Arbulo, quien llega a acusar a Juni de mal cristiano, seguramente en recuerdo del proceso inquisitorial que se le había seguido cinco años antes y que parece aflorar en estas declaraciones ${ }^{16}$ : ... de veynte e çinco años que le conoçe e le a conversado muchas de esas vezes, le tiene por hombre enemigo capital de la naçión hespañola, hespeçialmente de los ofiçiales de su arte; porque hes amigo de dezir mal despañoles, de les azer el mal que puede en público y en secreto. Porque andando heste testigo y él tassando el dicho rretablo, e yendo en la dicha tasaçión en una conformidad, e visto lo que llegaba la obra del dicho rretablo, se bolbió atrás gran suma de ducados de lo que entranvos en conformidad tenían tasado, y sintió heste testigo en él que le pesaba que castellano ubiese echo obra tan prenzipal e rrica, que balyesse tanto dinero. Demás e alliende que dél tiene entendido disinhyos de no buen cristiano, e por hesto sabe lo que dicho tiene de suso. E que a un hijo del dicho Juan de Juany, que se dize yjo, que le hoyó dezir que el dicho su padre no hestaba vien con el dicho Pedro López de Gámiz.

Los testimonios son muy expresivos del resentimiento de muchos de estos escultores contra Juni. Éste se había convertido en la década de 1550 en el principal referente de la escultura de la mitad norte de Castilla, una vez desaparecido Bigarny y con Berruguete desplazado a Toledo. Su taller vallisoletano atrajo a los imagineros y entalladores más dotados del reino, también a los burgaleses, riojanos y vascos. Muchos de ellos confiesan haber trabajado para él. Lo había hecho Juan Fernández de Vallejo, pero también López de Gámiz, según informa el propio Juni. Lamentablemente nada dice Anchieta, que podría haber aclarado definitivamente su relación con Juni, aunque es indudable que también trabajó en su casa. De entre los ensambladores, Mateo de Murga y Juan de Ybardia reconocen haber labrado en su taller.

La fuerte exigencia de Juni sobre sus oficiales y la xenofobia parecen estar en el origen del resentimiento. Quizás también una sinceridad a veces ofensiva. El propio Gámiz tuvo que sentirse molesto al conocer la paternalista declaración de Juni, donde divulgaba la participación de Gámiz en obras de este testigo para averse de aprovechar de su arte. Visto el tono displicente empleado por Juni, no es de extrañar la reacción desairada de Gámiz.

\section{Juan de Anchieta, escultor principal del retablo}

En la reciente monografía de García Gainza sobre Juan de Anchieta, publicada una vez entregado este artículo a Archivo Español de Arte, se hace un acertado estudio del retablo de Santa Clara, que me exime de reseñar las fluctuaciones que en la historiografía ha tenido la participación del vasco en la obra ${ }^{17}$. Esta autora recoge la última y crucial aportación de Martín Miguel ${ }^{18}$, para atribuirle al vasco lo mejor de los retablos de Santa Clara y Santa Casilda.

Nada hay tan taxativo en las declaraciones de los testigos del pleito de Briviesca como lo expresado por Esteban Velasco en 1575, que aclaraba que el retablo de las monjas de Briviesca lo había hecho Anchieta. Lo que sí permite el documento es certificar la participación crucial del guipuzcoano en Santa Clara, cuyo arte es motivo de alabanza por parte de todos los testigos, y concretar algunos extremos que coinciden básicamente con lo afirmado por García Gainza.

\footnotetext{
${ }^{16}$ Hay que recordar que muchas de las intervenciones del Santo Oficio se iniciaban a partir de acusaciones anónimas. ¿Se refiere a esto Vallejo cuando recuerda las presuntas maledicencias de Gámiz hacia Juni?

17 Juan de Anchieta, escultor del Renacimiento, Madrid, 2008, pp. 127-137.

${ }^{18}$ Martín Miguel, M. a A., Arte y cultura en Vitoria durante el siglo XVI, Vitoria 1998, p. 370.
} 
El primero en ensalzar la labor del vasco en el retablo de Santa Clara, precedente del elogio que dictará en su testamento, es Juan de Juni: Que Juan de Ancheta, puesto que es moço (sic por "aunque es soltero y no maestro"19), es mui buen ofiçial descoltura, labró en la dicha obra del dicho rretablo, a lo que este testigo tiene entendido, lo mejor dél. De la misma opinión son sus compañeros Juan de Salamanca, Sebastián de Burgos y Alonso Falcote. Este último, por ejemplo, declara: que conoce a Juan de Ancheta, el qual dixo a este testigo en Valladolid que venía a trabajar en la dicha obra del dicho rretablo. Y este testigo en las figuras dél conoze ser de su mano. E quel susodicho es de los buenos ofiçiales del rreyno.

En similares términos se expresan los artistas burgaleses Diego de Torres y Juan de Miranda. Su fama alcanzaba incluso a los eclesiásticos, acostumbrados a tratar con los artistas. Juan Marroquín de Montehermoso, racionero de la colegiata de Briviesca, confiesa que uno de los oficiales de Gámiz, que se dize Juan de Ancheta, entre ofiçiales de la dicha arte a oydo dezir por público quel susodicho es muy buen ofiçial, y de los vuenos que de presente se allan...

Indudablemente, Anchieta es el artífice principal del retablo de Briviesca, pero ¿en qué medida?

Las mejores imágenes de Santa Clara se pueden individualizar sin excesivos problemas, pero son tantas que hay que suponer a Anchieta autor de la mayoría del retablo. Por otro lado, la uniformidad estilística es tan alta que es preciso interrogarse sobre el origen de los modelos y sobre la dirección ejercida por Gámiz.

Lamentablemente, Anchieta no concreta los años que estuvo trabajando en Briviesca, únicamente se limita a declarar que labró allí durante mucho tiempo. Sabemos, además, que su estancia en La Bureba no fue continuada, sino que iba y venía a Valladolid; de hecho en agosto de 1568 estaba en la villa del Pisuerga ${ }^{20}$. Lo que sí queda claro en el pleito es que Gámiz llamó a Anchieta desde el principio. Éste acudió a Briviesca cuando se recibieron los dos bancos que dejó comenzados Guillén, por lo que pudo participar tanto en la imaginería como en las modificaciones compositivas de la arquitectura del retablo.

Respecto a este último extremo es muy significativo el distinto tratamiento de la calle central, sobre todo en el segundo y tercer órdenes, donde se alojan las imágenes de la Virgen de Anchieta, cuya rotundidad y simplicidad contrasta con los titubeos y vacilaciones que se observan en el resto de la obra. Los testigos informan que Gámiz decidió modificar totalmente la caja central del primer cuerpo: la ensanchó, eliminó el relieve del Abrazo ante la Puerta Dorada -ahora en el cuarto orden- y separó la imagen de la Virgen del segundo cuerpo, que originalmente debía rematar el árbol. Sin embargo, a pesar de estos cambios, Gámiz respetó el nicho propuesto por Guillén (similar al de Salas de los Infantes) y articuló un arco rebajado, que en ningún caso llega a formar una serliana, que invade ligeramente el orden superior. Estos titubeos quedarán solucionados en los cuerpos superiores, donde las cajas que cobijan las imágenes de Anchieta aparecen debidamente perfiladas por sencillas fajas molduradas, coincidentes con las habitualmente empleadas por Anchieta (Aoiz, Tafalla...).

Algo similar ocurre en los marcos de los relieves de las calles laterales. En el primer cuerpo se reelaboró un típico remate burgalés -veneras con colgantes carnosos-, que había sido utilizado ampliamente por Guillén, y al que no es ajeno Gámiz (Santa Casilda de Briviesa, Ircio y Vallarta). Este adorno se sustituyó en los órdenes superiores por clásicos frontones triangulares con ignudi recostados.

Los titubeos reaparecen en los remates. Estos, desmesurados, alcanzan la categoría de cuarto orden, pero sin respetar la traza seguida hasta entonces. De hecho, este ático es significativa-

19 Esta deposición de Juni realizada en el verano de 1572, semejante a la de otros muchos testigos, obliga a retrasar el matrimonio de Anchieta, que hasta ahora se creía de hacia 1570.

${ }^{20}$ MARTí Y Monsó, J., ob. cit., pp. 484-5. 
mente más bajo que los cuerpos anteriores; la calle central se divide, como ha apuntado Gainza, en tres partes, recreando el diseño previsto por Guillén en la traza original; se multiplican las convexidades recogidas del retablo de Santa Casilda; y, por último, se eliminan algunos elementos inherentes al retablo, como las reiterativas columnas o los adornos del friso. Su solidez, mayor austeridad y forma apaisada constituyen un adecuado remate para esta enorme máquina excesivamente vertical.

Mayor papel jugó Anchieta en la escultura. Él mismo recordaba durante el pleito cómo en los bancos de Guillén se añadieron muchas cossas de ymaxenería para adornar e perfiçionar e ynrriquizer los dichos dos bancos. Igualmente el vasco relata con precisión la sustitución de los relieves que Guillén había previsto para la predela: ...al tienpo que se yba asentando el primero banco, ...(el) probisor... dixo... que para la perfiçión del dicho rretablo le paresçía que la Entrada de Jerusalén o la otra Salida de Jerusalén con la cruz a cuestas, ...no se asentasen allí, e que en lugar dellas se pusiere... la Çena y el Labatorio...

Muchos testigos expresan la facilidad para distinguir lo ejecutado por Guillén de lo introducido por Gámiz. Como dice Fernández de Vallejo ...en el dicho rretablo se be claramente qual hes lo labrado por Diego Guillén e qual hes lo que a labrado el dicho Pedro López de Gámiz, porque entre maestros artifizes bien entendidos conoçen la obra del uno e la del otro como entre dos escrivanos conoçe cada uno ssu letra. Incluso el color de la madera ayudaba y ayuda todavía hoy. Guillén hizo la mazonería en madera clara de roble y las tallas en nogal más oscuro, mientras que Gámiz utilizó solamente el nogal. De hecho, se llegaron a retocar algunas piezas, como los mensulones con los atlantes semidesnudos, que presentan algunos añadidos de nogal y que fueron retallados por Anchieta. Se respetó el Jessé de Guillén, aunque el árbol se talló de nuevo. La calidad del vasco tuvo que afirmarse desde el primer momento, puesto que las imágenes del banco y primer cuerpo, con excepción del Jessé y las dos figuras más cercanas al relicario, le pertenecen. El propio Anchieta hizo los dos relieves que exigió el veedor del condestable cuando se estaba asentando la predela.

La excelencia de Anchieta y la menor categoría del resto de los oficiales, patente, por ejemplo, en la cabeza añadida del apóstol del primer plano del relieve de la Santa Cena, tuvieron que convencer a Gámiz para dejar en manos de su mejor oficial las esculturas más destacadas. Como ha apuntado García Gainza son de Anchieta las grandiosas imágenes de la Virgen de la calle central, los seis relieves de las calles laterales y la mayoría de los bultos redondos de apóstoles y santos de las entrecalles. No le pertenecen las imágenes del cuarto orden, ni las pequeñas figuras de las entrecalles que lindan con la parte interior de las columnas achaflanadas.

Mayores problemas suscitan las figuras del remate. Sabemos por la información que proporciona el pleito que Anchieta estaba en Briviesca en agosto de 1569, ocupado en terminar las imágenes del segundo y tercer cuerpos. Dichos órdenes quedaron asentados en septiembre. Al mes siguiente Gámiz firmaba el último contrato del retablo, pero graves problemas económicos le obligaron a ralentizar los trabajos, lo que motivó la partida de Anchieta. En 1570 fue reclamado para trabajar en el retablo de la capilla de Gabriel Zaporta de la Seo de Zaragoza. Allí permaneció hasta marzo de 1571 en que recibió el finiquito ${ }^{21}$. Precisamente en ese mismo mes de marzo se tenía que terminar el retablo de Briviesca; y aunque Gámiz se demoró unos meses en concluir la obra, no parece que el vasco regresara a la villa.

En definitiva, el cuarto cuerpo y los remates se tallaron mayoritariamente en ausencia de Anchieta, apreciación que confirma el análisis estilístico. Las esculturas menos anchietianas del retablo son las del Calvario. El Cristo crucificado y los Ladrones, anatómicamente muy exage-

${ }^{21}$ SAn Vicente, A., «La capilla de San Miguel del patronato Zaporta, en la Seo de Zaragoza», AEA, XXXVI, 1963, p. 107. 
rados, no corresponden al estilo del vasco, mientras que la Magadalena, la Virgen y el San Juan son verdaderamente torpes y parecen realizadas por la mano que talló mayoritariamente el último cuerpo. Mayor nobleza transmiten los Profetas, esculturas excelentes, dignas de las mejores creaciones del guipuzcoano.

Con todo, el retablo en su totalidad, a excepción de las escasas figuras de Guillén, hace gala de una unidad estilística notable, basada por lo general en los modelos del vasco. Puede parecer sorprendente que, en el marco de un rígido sistema gremial, un oficial lograra imponer su estilo; pero ni la producción anterior de Gámiz, ni la posterior, alcanzan la grandiosidad y severidad desplegadas en Briviesca. Gámiz, consciente de la superioridad de Anchieta se vería obligado a solicitarle gran parte de los modelos.

La excelencia de lo obrado por Anchieta en Briviesca tuvo que estar precedida por una prolongada práctica escultórica. El reciente artículo de Redondo Cantera, en el que dio a conocer el aprendizaje del vasco con Antonio Martínez ${ }^{22}$, y la consideración por parte de García Gainza de su participación en el retablo de Astorga, abren todo un abanico de posibilidades para tratar de desentrañar la labor realizada antes de trasladarse a La Bureba.

La declaración de Juan de Salamanca en el pleito de Briviesca, donde dice que ...en el rretablo quel dicho Pero López tiene asentado (en Santa Clara), e figuras que este testigo en él a visto, le pareszen ser de la mano del dicho Ancheta, porque a visto otras muchas cosas de su mano... permite aventurar que la producción del guipuzcoano se concentró en Valladolid y alrededores, donde residían ambos.

El prestigio alcanzado por Anchieta, manifestado en los testimonios reseñados más arriba, y el hecho de que contara ya con un aprendiz en 1567 indican una actividad creciente en la entonces villa del Pisuerga. Su participación en el mercado escultórico vallisoletano se enmarcaría principalmente en la obra de otros maestros, pero tuvo necesariamente que realizar algún encargo menor por su cuenta.

El intento de descubrir la mano de Anchieta en el Valladolid de la década de 1560 supera las intenciones de este artículo; pero por su importancia, dado que permitirá descubrir los inicios del principal representante de la escultura romanista, será objeto de un próximo estudio.

Fecha de recepción: 12-VI-2007

Fecha de aceptación: 20-II-2008

22 «El aprendizaje y los años vallisoletanos de Juan de Anchieta», Memoria Artis, Santiago de Compostela, 2003, pp. 487-8. 